\title{
Zbigniew Chojnowski*
}

\section{Antyczne zainteresowania oraz inspiracje Wojciecha Bąka}

DOI: http://dx.doi.org/10.12775/LC.2018.050

Streszczenie: Antyczne zainteresowania oraz inspiracje Wojciecha Bąka wynikały z jego wychowania i ukształtowania w kulturze humanistycznej, opartej na tradycji chrześcijańskiej i grecko-rzymskiej. Spektakularnie nawiązywał do dziejów i dzieł starożytnych w dramatach, a w mniejszym stopniu w eseistyce. Intrygowało go wyłanianie się w kulturze początków ery chrześcijaństwa. Wierszy nie inkrustował antycznymi motywami. W liryce Bąka bezpośrednie nawiązania do klasyki greckiej i rzymskiej są nieliczne i nie mają charakteru językowo-stylizacyjnego. Poeta próbował twórczo kontynuować ideę orfizmu, która przybrała postać „śpiewnej samotności”, łączącej świat zmysłowy z rzeczywistością transcendentną. Podstawowymi celami poezji są: „pochwała” bytu, odsłanianie „przestrzeni wiecznej”, otwieranie nowych perspektyw duchowych. Należał do twórców niezłomnie wierzących w niezbywalność kulturowego dziedzictwa starożytnych jako fundamentu cywilizacji.

Słowa kluczowe: Animula vagula blandula, Tyberiusz, orfizm, Arion/Arijon, Wojciech Bąk

\section{Wojciech Bąk’s Antique Interests and Inspirations}

\begin{abstract}
Wojciech Bąk's interest in and inspiration drawn from the Antiquity was the result of his upbringing and formation in the humanist culture based on Christian and Greek-Roman traditions. Bąk alluded to Antique history and culture in a spectacular way in his plays, to a lesser degree in his essays. He was intrigued by the cultural aspects of the emergence of the Christian era. He did not overload his poems with Antique motifs. In Bąk's works direct references to Greek and Roman classic works are scarce and are not used for stylistic purposes. The poet attempts to offer a creative continuation of Orphism, which takes the shape of "melodic loneliness", connecting the sensual world
\end{abstract}

* Profesor w Zakładzie Literatury Współczesnej i Teorii Literatury Uniwersytetu Warmińsko-Mazurskiego w Olsztynie. Zajmuje się poezją polską XX wieku. E-mail: zbigni@gmail.com. 
with transcendent reality. The basic aims of poetry are the following: "praise" of being, unveiling the "eternal space", opening new spiritual perspectives. Wojciech Bąk was one of the artists who adamantly believed that the cultural heritage of Antiquity constitutes a fundament of civilization.

Keywords: Animula vagula blandula, Tiberius, Orphism, Arion, Wojciech Bąk

isarstwo Wojciecha Bąka (1907-1961) przesłonił los, a szczególnie okres prześladowań stalinowskich. Opisywany przez Józefa Ratajczaka (1993: 154-170), Witolda Banacha (2005), Joannę Siedlecką (2005), Tomasza Sikorskiego (2016) ${ }^{1}$, Tomasza Pyzika (2007) i innych ostracyzm literackiego środowiska Poznania, osadzenie twórcy w „psychuszce” w Dziekance pod Gnieznem, inwigilacja tajnych służb i próby sądownego ubezwłasnowolnienia go, odsyłają niezniewolone przez bieżące okoliczności dzieło literackie Bąka w cień. Po 1989 roku badania zorientowane na wewnętrzną specyfikę twórczości reprezentują prace niewielu krytyków i badaczy literatury XX wieku, m.in. Eugeniusza Sternę-Wachowiaka (1996: 13-18), Tomasza Pyzika (2007), Grzegorza Kubskiego (2006: 11-38), Dobrochny Ratajczakowej (2006: 39-52), ks. Jana Kantego Pytla (2006: 61-68), Witolda Sadowskiego (2009), Zbigniewa Chojnowskiego (2011: 95-111) czy Ewy Borkowskiej (2012-2013: 87-96; 2016). Kornelia Ćwiklak (2014) podjęła refleksję nad miejską topografią literacką u Bąka. Miłosz Piotrowiak opracował artykuł porównawczy Do-tkliwość wojny: „Omijam czule trawy, kiedy idę droga... ” Wojciecha Bąka i „Drach” Szczepana Twardocha (Piotrowiak 2015).

Antytotalitarna postawa i bunt tego tyleż zapomnianego, co nieznanego i wciąż niedostatecznie rozpoznanego poety, dramaturga, eseisty, tłumacza, redaktora miały złożone i apolityczne źródła. Twórca z racji wychowania, drogi edukacyjnej, osobistych poszukiwań, a wreszcie pogłębianej w kulcie dla antyku tradycji humanistycznej umacniał i rozwijał przynależność literatury polskiej do śródziemnomorskiego kręgu kulturowego. Reprezentował postawę chrześcijańskiego neoklasycysty. W liście do „Obywatela Prezydenta” Bolesława Bieruta z 26 kwietnia 1952 roku wyznał otwarcie, że ma „umysłowość wykształconą na chrześcijaństwie i kulturze grecko-rzymskiej” (list w całości cytuje Banach 2005: 113-115).

Pisarza zajmował z jednej strony świat chrześcijański, z drugiej antyk Greków i Rzymian. Zainteresowania te, zaszczepione przez ojca, podtrzymywała edukacja w katolickiej szkole powszechnej w Ostrowie Wielkopolskim i tutejszym Królewskim Katolickim Gimnazjum. Na młodego Bąka wpłynął autorytet filologa klasycznego prof. Tadeusza Eustachiewicza (ojca literaturoznawcy i tłumacza Lesława, który żył w latach 1913-1998) (Sikorski 2016: 39-42, 46). Poeta na Uniwersytecie Poznańskim odbył studia filologiczne, estetyczne i filozoficzne. W formowaniu się jego osobowości twórczej niepoślednią rolę odegrał „podziw dla antyku” (ibid.: 55). Przez całe życie fascynacje historią i kulturą starożytnych wiązały się u Bąka z płomiennie i niezłomnie wyznawaną wiarą chrześcijańską.

1 Zawiera się tu najobszerniejsza bibliografia podmiotowa, przedmiotowa (niepełna) i kontekstowa W. Bąka (Sikorski 2016: 413-462). 
Jeszcze w dzieciństwie poety zaciekawienie kulturą antyczną wywołał u niego ojciec, Franciszek Bąk, który swojemu dziecku czytał Iliadę Homera. Wojciech jako już dojrzały człowiek wspominał:

Starożytny poemat był dla niego uroczystą powieścią historyczną, w której zachwycało go wszystko. Jedyną trudność sprawiali mu bogowie, których zresztą uważał za przebranych ludzi, udających bogów. Co prawda niewytłumaczalne było, że w mgnieniu oka przebywali niezmierzone przestrzenie, znikali i pojawiali się niespostrzeżenie. Nie był on jednak pedantem w sprawach poezji i cała tajemnicza sfera bóstw nie tylko odbierała poezji w jego oczach uroku - przeciwnie, zachwycała go, narzucając próby wytłumaczenia sobie jego niezwykłości (Bąk 2007: 38).

Homerycka epopeja obudziła w kilkuletnim chłopcu wyobraźnię, w której pojawiły się plastyczne wizje scen batalistycznych. Wraz z nimi przyszło trwałe doświadczenie związane z oddziaływaniem utworu literackiego. Odbiór dzieła (słuchanie lub czytanie) umożliwia jednoczesne przebywanie w dwóch różnych miejscach i czasach:

Niepamiętny, że tkwisz ciałem w czterech ścianach ciasnego domu w dalekim od pobojowiska mieście, kroczysz wśród szeregów achajskich, czujesz na sobie nagolenniki i błyszczący hełm z pióropuszem (ibid.).

Przeżycia były na tyle silne, że chłopiec postanowił zostać „dziecięcym Homerydą” i zaczął pisać własną Iliadę (zob. Borkowska 2017: 75-76, 78). Doznania wywołane przez epopeję Homera zapoczątkowały u Bąka myślenie o literaturze wyznaczone przez perspektywę arcydzieł. Twórca zarówno lekturę utworów, jak i ich pisanie, traktował jako formę przebywania (mówiąc formułą Zygmunta Kubiaka) w „przestrzeni dzieł wiecznych” (Kubiak 1993). Z punktu widzenia Wojciecha Bąka nie stanowiły one zasobu do snucia analogii między tym, co zamierzchłe, a tym, co współczesne. Przedziały między epokami, stuleciami i pokoleniami znosiło przekonanie o ponadczasowości wszelkich wydarzeń i losów. Nie traktował dorobku pisarskiego starożytnych jako materiału do literackiej inkrustacji lub popisów erudycyjnych. Nie dążył do naśladownictwa antycznych wzorów, wszak konsekwentnie sprzeciwiał się wszelkiemu formalizmowi, który czyni z literatury sprawę technê i rodzi martwe zagadnienia. Pozostawał wierny mniemaniu, że dzieło, a zwłaszcza arcydzieło literackie wyraża żywą i rozwiniętą lu d zką osobowość twórcy, odczuwającego i utwierdzającego realność wartości i praw „wiecznotrwałych”.

Bąk jako wyznawca chrześcijaństwa o wykształceniu klasycznym był daleki od historyzmu, ale też od postawy sprzyjającej strukturalizmowi; choć jednym z apologetów młodzieńczej poezji Bąka w latach trzydziestych był prekursor badań strukturalistycznych w Polsce, Konstanty Troczyński, który pisał:

w poezji polskiej współczesnej na plan pierwszy wysunęły się indywidualności twórcze, nienależące ani do „Skamandra”, ani do awangardy - Wojciech Bąk, Czesław Miłosz, Konstanty Gałczyński (Troczyński 1938: 27; 2003: 29).

Nadzieję na rozwój polskiej poezji wiązał z przyszłymi dokonaniami wymienionych ówczesnych trzech debiutantów. 
Mimo tonacji kasandrycznej i katastroficznych nastrojów, wojenno-okupacyjnych doświadczeń, represji i opresji w ostatnim okresie życia, Bąk konsekwentnie podtrzymywał pogląd, że istotą wszelkiej sztuki, wywiedzioną z kultury antycznej, jest „pochwała” (Bąk 1968: 252). Chwalić znaczyłoby tu stwarzać „wizję wyższego porządku świata”, w której to, co zmysłowe, nabiera wartości. A dalej: ze zwykłych doznań budować porządek, czyli przenosić „materiał chaotyczny” w wymiar wartości. Celem sztuki, a w tym poezji, jest znajdowanie dla tego, co przeżywane, doświadczane, związków ze światem idei, który jako byt realny gwarantuje wieczną nienaruszalność wartości.

Poznański badacz Michał Jaworski w monografii Mit Orfeusza w literaturze polskiej XX-XXI wieku zbył milczeniem orfizm poznańskiego twórcy, Wojciecha Bąka (Jaworski 2017). A przecież był on poetyckim chrześcijańskim platonikiem. Przejawem Bąkowego orfizmu w całej twórczości jest „śpiewność” i „śpiewanie”, słyszenie „śpiewu”, pragnienie bycia nim i w nim. W orfickim „śpiewie” zawiera się nie tyle estetyzm, ile głęboki sens etyczno-religijny.

Krytycy w latach trzydziestych nie mieli wątpliwości, że Bąk wyznawał i uprawiał poezję jako rodzaj twórczości znajdującej się u źródeł religii (Czernik 1938: 7). Jak można przypuszczać, poecie bliskie było stanowisko Platona wobec orfizmu pierwotnego; filozof pod koniec życia przychylał się do następującego poglądu:

Trzeba istotnie wierzyć dawnym i świętym orędziom, które nam głoszą, że dusza jest nieśmiertelna, że staje przed sędziami i że grożą jej najsroższe kary, skoro uwolni się od ciała. Toteż należy uważać za mniejsze zło, jeżeli ktoś pada ofiarą wielkich krzywd i zbrodni, niż jeżeli sam je popełnia (Czernik 1938: 7).

Stwierdzenie Platona podsuwa przesłanki zarówno do opisu losu Bąka, jak i postawy reprezentowanej w jego utworach. Podstawę światopoglądową tekstów określa bowiem zgoda na bycie ofiarą „wielkich krzywd i zbrodni”, wola utrzymania swojego miejsca po stronie „światła”, dobra, moralności, mocy uzdrowicielskiej, życia dla pomyślnej, choć odległej w czasie, przyszłości.

Jedna z etymologii imienia „Orfeusz” wskazuje na tego, który uzdrawia światłem. Inny źródłosłów wskazuje na to, że Orfeusz w odróżnieniu od Ariona, śpiewaka publicznego i schlebiającego gustom wszelakim, jak to dzieje się w wierszu Arijon Zbigniewa Herberta (Herbert 2008: 72-73), jest sierotą, samotnym śpiewakiem, idącym pod prąd. Ponadto ironicznie przedstawia Herbert „Arijona” jako poetę-śpiewaka, który swoim śpiewem zaprowadza iluzoryczny porządek. Jerzy Wiśniewski trafnie interpretuje:

Śpiew Herbertowego Arijona jako symbol stereotypowo pojmowanej sztuki klasycznej, nienaturalnie idealizującej rzeczywistość, jest nie do zaakceptowania z perspektywy doświadczeń człowieka dwudziestego wieku. Ocalenia godna wydaje się jedynie idea przywracania przez poezję harmonii w świecie, o ile równocześnie dochowuje się wierności prawdzie (Wiśniewski 1998: 19).

Michał Jaworski w „Arijonie” Herberta dostrzega „Orfeusza radosnego, oglądanego wyłącznie z jednej strony, pozbawionego rysu dramatycznego” (Jaworski 2017: 316). Postawienie tu znaku równości między „Arijonem” a Orfeuszem jest jednak problematycz- 
ne, zwłaszcza że Andrzej Maria Kempiński w Słowniku mitów muzycznych podaje, że Arion był „jak Orfeusz” (Kempiński 2002: 32-34).

Postać Ariona trudno spotkać w literaturze polskiej. Aleksander Kraushar (18431931) w poemacie Arion $z$ Koryntu, który wszedł do zbioru poezji Tytan. Arion $z$ Koryntu (Kraushar 1866: 41-68), wykreował Ariona na modłę romantyczną. Narzucił mu rolę Wajdeloty, który poderwawszy Hellenów do boju przeciw Rzymianom, ginie od ciosów wroga.

Nieschlebianie temu, co oficjalnie uznane i wymagane przez aktualną władzę, charakteryzuje zarówno przyjętą przez Bąka postawę literacko-społeczną, jak i zaprojektowanego przez niego bohatera lirycznego. Tak czy inaczej jego orfizm odwołuje się do poezji jako formy poznania jedności dzieła stworzenia i Bożych - nie na miarę człowieka - tajemnic. Bąk, wierny orfickiemu posłannictwu poety, od początku swej drogi podążał samotnie (tytuł drugiego tomu wiersza Wojciecha Bąka z roku 1936 nosi tytuł Śpiewna samotność, a wybór jego poezji w układzie i z posłowiem Romana Bąka, bratanka Wojciecha, zatytułowano W samotności; Bąk 1997).

Więź z Orfeuszem poeta wypowiedział w autodefinicji, znajdującej się w tytułowym cyklu Zastygłe chwile, pisanym podczas przymusowego pobytu w „psychuszce” w Dziekance w połowie lat pięćdziesiątych. Strofy wypełniają śpiew - żal, trwoga - zachwyt i testamentalne sumowanie życia. Wiarę w orfejskie przeznaczenie wyznaje w czterowierszu czterdziestokilkuletni mężczyzna:

Orfeusz umiał śpiewem uciszać zwierzęta,

A mój śpiew często ludzi nawet nie porusza -

A przecież kto zaprzeczy, kto mój głos pamięta -

Że żyła we mnie dusza Orfeusza!

(Bąk 1958: 127)

Według Bąka antyk przekazał potomnym jedyne istotne rozumienie Orfeusza jako „świętego tłumacza bogów” (Bąk 1968: 253). Toteż przykładając do poezji tę miarę, odmawiał wielu modernistycznym poetom wielkości i zarzucał im skłonność do ucieczki w piękność i estetyzację. Twierdził np.: „A jednak jako »interpres deorum [interpretator bogów przyp. Z. Ch.] « Rilke zawodzi” (Bąk 1968: 253). Według wielkopolskiego twórcy orfickie kryteria spełniają arcydzieła autorów nazywanych przez niego „bliskimi krewnymi ducha” (Bąk 1960: 70), czyli: Homera, Ajschylosa, Eurypidesa, Sofoklesa, Arystofanesa, Pindara, Hezjoda czy Horacego, Wergiliusza, Dantego, Szekspira i im podobnych.

W tekstach Bąka najczęściej występują odniesienia do Biblii i historii Kościoła katolickiego, z zasady nie ma w nich motywów mitologii greckiej lub rzymskiej. Poetę intrygowały niejednoznaczne i krwawe dzieje starożytnych spisane przez Tacyta oraz starogreckie tragedie, m.in. jako mistrzowskie utrwalenie ścierania się zagadnień wiecznych, których nie można pogodzić $\mathrm{z}$ ludzkiego punktu widzenia.

Antyk Bąka jawi się jako świat bliski, znajomy, nie tylko dlatego, że jego postrzeganie jest schrystianizowane i w pewnym sensie odhistorycznione. Świat antyczny ma tu wymiar personalistyczny. Bąk przywołuje starożytność poprzez jej wybitnie słynnych przedstawicieli. Kiedy mowa o dziełach, zjawiają się one jako emanacje zarówno wyznawanych przez pisarzy i poetów antycznych idei, jak i ich temperamentów, zapatrywań, duchowości. 
W utworach Bąka pewien niepokój, niedosyt i lekturowy krytycyzm budzi ogólnikowy charakter reminiscencji antycznych. Autor był obdarzony w większym stopniu umiejętnością syntezy, a w mniejszym analizy. W tekstach eseistycznych, nazywanych przez niego „rozważaniami prozatorskimi”, chętniej formułował całościujące intuicje, unikał zaś brania roztrząsanych kwestii pod filologiczno-filozoficzną lupę. Nie oddawał się drobiazgowej argumentacji. Chwalił albo ganił, akceptował albo odrzucał. Pryncypializm i kategoryczność głoszonych poglądów i wydawanych opinii potwierdzają jego pasję, z jaką dążył do unaocznienia, że jest możliwy jeden jedyny pogląd na daną sprawę. Osłabione w tekstach działanie wewnętrznej dialogiczności i dyskursywności niejako wyrównuje świadomość, że powstały one jako „gorący” głos polemiczny wobec kultury, literatury, oddającej się „formie”, wspó1uczestniczącej w pozoracji umysłowego życia, odcinającej się od refleksji etycznej, niezwiązanej z duchowymi doświadczeniami osoby, uprzedmiotowionej przez politykę itd. Antyk służył Bąkowi jako płaszczyzna umożliwiająca postawienie fundamentalnych spraw człowieka i człowieczeństwa w perspektywie przełamującej doraźność i krótkowzroczność dalekiej od utylitaryzmu i jakiejkolwiek propagandy.

W dorobku pisarskim Wojciecha Bąka uwidoczniły się pewne prawidłowości, dotyczące natężenia i sposobu występowania antycznych motywów (a w tym problemów, z jakimi zmagali się starożytni). W opowiadaniach ze zbiorku Twarze uobecniają się śladowo, np. szpitalna narracja Nie ma rady ilustruje przetworzoną sentencję Seneki: „Nie śmierci się boimy, ale umierania” (Bąk 1948: 5). Wskazanym tu tropem doświadczenia granicznego poszedł Wiesław Trzeciakowski, pisząc artyku1 „Nie śmierci się boimy, ale umierania”. Analiza wiersza IV z cyklu „Wiersze szpitalne” Wojciecha Bąka w kontekście sytuacji umierającego człowieka (Trzeciakowski 2007).

$\mathrm{W}$ wierszach antyczne aluzje pojawiają się rzadko i epizodycznie, naliczyłem zaledwie kilkanaście liryków o tematyce ściśle związanej z kulturą/literaturą antyku. Jeśli można tak powiedzieć, uobecnia się ona na ogół poza stylem. Autor zrezygnował ze stosowania w swoich tekstach antyczno-literackiej patyny.

Dziedzictwo starożytnych jest reprezentowane w sposób skondensowany w opublikowanym dramacie Bąka Tyberiusz (Bąk 1937). W rękopisach pozostają: Upadek Kartaginy, Agrypina, Piłat, Święty Pawet, Święty Augustyn. Ich tematyka potwierdza szczególne zainteresowanie autora rodzeniem się chrześcijaństwa, czego najpełniejszy wyraz dał w książce O Bogu - Człowieku i apostołach (Bąk 1971). Bąkową dramaturgię opartą na dziejach Rzymu scharakteryzowała Ewa Borkowska:

Obok Tyberiusza pojawia się Agrypina i Upadek Kartaginy. Agrypina to dramat dynamiczny, bogaty w perypetie, wątki melodramatyczne w powiązaniu z kryminałem. Jednak nie o wątki sensacyjne chodzi, a raczej o ideę historiozoficzną i powiązanie z rozprawą na temat starożytnego Rzymu. Był on dla Bąka swoistym mitem, symbolem prawa, dyscypliny, harmonii - wyimaginowanym odzwierciedleniem wartości społecznych. Upadek Kartaginy również powiązany jest z przyjętą przez pisarza koncepcją Rzymu, ponieważ stanowi poetycki przegląd wydarzeń związany z trzecią wojną punicką. Należy podkreślić, że dramat odsłania patriotyczny heroizm Kartagińczyków (Borkowska 2012-2013: 94-95). 
Tyberiusz $z^{2}$ przedstawia schyłkowy okres panowania tytułowego cesarza rzymskiego i zamieszkiwania na Capri (lata 31-37) ${ }^{3}$, a w rzeczy samej jest to studium władzy opartej na bezwzględnej przemocy, odrzuceniu etyki i lekceważeniu duchowości. Dramaturg zainscenizował twierdzenie Swetoniusza i Tacyta, że Tyberiusz padł ofiarą Kaliguli i dowódcy pretorianów Makrona. Z wizji Imperium Rzymskiego wyziera wszechobecny strach i zabójcza podejrzliwość. Brak wolności powoduje zatracenie ducha. Tyberiusz jest władcą państwa rozkładającego się od środka, przygnieciony ciężarem odpowiedzialności za nie pogardza ludźmi i wszędzie widzi zło. Ma rysy okrutnego despoty, gdy określa okrutną przesłankę swoich rządów. Państwo opiera się na wymuszaniu ślepego posłuszeństwa władzy, politycznemu instrumentalizowaniu instytucji oraz prawa, a nie na sprawiedliwości. „Program polityczny” określa w tyradzie:

TYBERIUSZ: (biorąc ze stołu spis nowych oskarżonych) Oto tutaj ojcowie jest spis szaleńców. Tu spisani są wszyscy, którzy bunt słowem lub czynem szerzyli. Waszą sprawą być ręką karzącą. Niechaj ręka baczy, żebym nie powiedział o niej, że jest zbyt słaba lub (drwiąco) za pobłażliwa. Nic wam nie nakazuję. Zwracam wam tylko uwagę, że lepiej jest, kiedy niewinny skazany zostanie niż kiedy winny umknie prawu. Lepsza jest śmierć tysiąca niewinnych z pożytkiem dla Rzeczypospolitej niż żywot jednego winnego na jej szkodę. (zimno) Kto nie ma dość zimnej krwi, kto nie ma umysłu dość jasnego, niechaj trzyma się z dala od spraw Rzeczypospolitej. Po co mu senat? Senat jest tylko dla twardych. To, ojcowie, pamiętajcie. To Rzym musi wiedzieć. Ja dziś widzę sprawy jasno ( $z$ naciskiem $)$ - i wy musicie jasno widzieć. Tego oczekuję, tego żądam. Tego oczekuje i żąda Rzeczpospolita (Bąk 1937: nr 13, 6).

Łagodnym i solidnym antagonistą Tyberiusza jest połączony z nim nicią przyjaźni Nerwa, upominający się o postępowanie nie z nienawiści i żądzy odwetu, lecz w imię wolności oraz miłości do życia i ludzi. Uosabia prefigurację chrześcijanina. Według Tyberiusza żądanie prawa do wolności oznacza to samo, co żądanie „obłędu”. Nerwa nie mogąc pogodzić się ze stosowaniem przemocy i bezprawia przez władcę, opuszcza go. A mimo to rzymski władca niedługo przed śmiercią zwraca się do nieobecnego przyjaciela najpierw: „Nerwo, Nerwo, nie zwyciężysz!”, a niedługo potem, gdy traci życie z ręki pretorianów na rozkaz ich dowódcy Makrona, krzyczy: „Nerwo, zwyciężyłeś!”. Zawołanie ma podobny sens do kwestii Pankracego z Nie-Boskiej komedii Zygmunta Krasińskiego: „Galilejczyku, zwyciężyłeś!” („Galilaee, vicisti!”). Pierwotnie słowa te przypisano Julianowi Apostacie (331/332-363), który miał je wypowiedzieć na łożu śmierci.

Bąk, prowadząc akcję dramatu zgodnie z przekazem Swetoniusza i Tacyta, ostatecznie przełamuje jednoznacznie negatywny wizerunek Tyberiusza. Ewa Borkowska celnie spostrzegła:

Co „zrobił” Bąk z Tyberiuszem? Nic innego, jak uczłowieczył go, czyniąc z niego tragicznego władcę targanego sprzecznościami, pozbawionego cech demonicznych, za to świadomego, że władzę musi przejąć zwyrodniały Kaligula (Borkowska 2012-2013: 93).

\footnotetext{
2 Sztukę wyreżyserował Jerzy Zegalski. Premiera odbyła się 12 października 1979 roku na Małej Scenie Teatru Dramatycznego im. Aleksandra Węgierki w Białymstoku.

3 W ostatnim czasie postać następcy cesarza Augusta uczynił główną postacią swej powieści Tyberiusz Cezar Jacek Bocheński. Jest to trzeci tom „trylogii rzymskiej” tego pisarza. Wcześniej wydał: Boskiego Juliusza (1961) i Nazo poetę (1969). Zob. Morawiec 2016.
} 
Dlatego w reminiscencjach z podróży odbytej między majem a sierpniem 1939 roku po Italii ${ }^{4}$, pisanych już po II wojnie światowej, postać władcy Rzymu jawi się Wojciechowi Bąkowi jako pokutująca przez wieki dusza, której wciąż bliżej do piekła niż do nieba:

Na Capri trwa do dzisiaj willa Tyberiusza,

Kroczyłem po jej schodach, błądziłem w ruinach -

Podobno nocą chodzi w tych zwaliskach dusza -

To Cezar zbrodnie swoje i gwalty przeklina...

Nie widziałem go wtedy. A teraz rozmawiam -

I widzę zgliszcza w prochu i wychudłą twarz -

I Cezar opowiada mi swoje bezprawia,

I pyta - jaki dzisiaj jest na ziemi czas?

Cezarze, nie ode mnie odpowiedzi czekaj,

Zbyt wiele zobaczyly moje smutne oczy -

I odchodzę - i tylko twarz widzę z daleka,

Na której płomień piekła się żarzy wśród nocy!

(Bąk 1958: 112)

Bąk zainteresowanie literaturą Greków i Rzymian utrwalił w eseistyce z tomów: Zagadnienia i postacie (1947), Szkice (1960), Wyznania i wyzwana (1968). Wśród ineditów jest Wprowadzenie do literatury greckiej, oraz inne pozycje rękopiśmienne, których zawartość hipotetycznie również w jakimś stopniu dotyczy refleksji nad kulturą antyczną (Poradnik dla literatów, Rozkład kultury, Stanowisko współczesne do Rzymu, Zagadnienia europejskie i literackie, Zagadnienia kulturalne i inne).

Wczesnym i rzadkim w swoim rodzaju przejawem Bąkowych zainteresowań epigramami łacińskimi jest wiersz Transkrypcja z cesarza Hadriana: Animula, vagula, blandula z nagrodzonego przez „Wiadomości Literackie” debiutu poetyckiego Brzemię niebieskie (1934):

Duszko trwożliwa, duszko pierzchliwa,

W ciele zgubiona jak w gęstym lesie;

Jakiż to wicher ciebie porywa

I wśród gałęzi jak piłkę niesie.

Tam nie zadymią jak kadzielnice

Sosnowych koron smukle amfory -

Lecz zapatrzone w chaos źrenice

Mdleją jak dżdżyste, wiejskie wieczory.

4 Jak pisze T. Sikorski, była „to podróż życia” Bąka, podczas której odbył „wędrówkę po zaginionym świecie antycznej cywilizacji, w której od najmłodszych lat był rozkochany". Twierdzenie Sikorskiego, że przewodnikiem peregrynacji był cykl felietonów Jerzego Waldorffa, najpierw zamieszczanych w „Prosto z Mostu”, a potem wydanych w książce pt. Sztuka pod dyktatura, Warszawa 1939, jest raczej przesadzone i domaga się dodatkowych wyjaśnień (zob. Sikorski 2016: 94). Waldorff z aprobatą wypowiada się tu o włoskim faszyzmie, czy też o futuryzmie, do którego Bąk odnosił się jednoznacznie krytycznie. Na temat zawartości książki Waldorffa zob. Meller 2009-2010: 105-121. Bąka w książce Waldorffa mógł zafascynować podzielany z nim podziw dla „ducha romańskiego". Rola Sztuki pod dyktaturq w podróży poety po Italii wymaga badań. Włoskie podróżowanie Bąka wpisuje się w dziewiętnasto- i dwudziestowieczną tradycję udawania się polskich poetów do Grecji i Italii jako źródeł kultury śródziemnomorskiej. 
Tam nie wytryska złotą fontanną

Wodotrysk nieba - słońce lipcowe -

Lecz ciszą głuchą i bezustanną

Jak mrozem wieje mrok zaświatowy.

Tam nie zadźwięczy taktem radosnym

Dziób kującego sosnę dzięcioła -

Zaświat bezkształtem, bezgłosem rośnie

I morzem pustki płynie dokoła,

Tam nikt nie wpatrzy się w twoje skoki,

Kiedy się huśtasz nad gałęziami -

Nikt nie posłucha w ciszy głębokiej,

Jak grasz wśród lasu miłym kukaniem.

Tam groźnie straszy wieczną północą

I chaos błędny krąży odmętem -

Bezświetlne gwiazdy w pustce trzepocą,

Kosmicznych orłów mumie wyschnięte,

Duszko trwożliwa, duszko pierzchliwa,

Kukułko słodka - pozostań z nami!

Jakiż to wicher ciebie porywa,

O, wędrowniczko ponad światami!

(Bąk 1934: 8-9)

Liryk Bąka jest przekładem i rozwinięciem pięciowersowego utworu Hadriana od słów Animula vagula blandula:

Animula vagula blandula

Hospes comesque corporis

Quae nunc abibis in loca

Pallidula rigida nudula,

$\mathrm{Nec}$, ut soles, dabis iocos.

Epigramat znamy z dawniejszego przekładu Kazimierza Morawskiego:

Duszyczko moja, tkliwa i ruchliwa,

Gościu ty ciała mego towarzyszko,

Co pójdziesz teraz w krainy ciemności,

Twarde i nagie, i pełne bladości,

A żartów stroić już zwykłych nie będziesz

(oba powyższe cyt. za: Morawski 1893: 96).

W ujęciu Morawskiego poetycka glosa Hadriana zawiera przeczucie chrześcijańskiego wyobrażenia śmierci: 
W Hadriana przedgrobowym wyznaniu mamy jednak najindywidualniejsze rysy znużonego życiem i niezbadanymi jego tajemnicami człowieka. W przededniu śmierci kreśli on w swych notatkach wierszyk do swej duszy [...]. A więc to były żarty, od których teraz odejść i wstać przyszło! Vanitas vanitatum Pisma św. znalazło taki wyraz w tej animula vagula, która czepiała się wszystkich darów życia i wszystkich życia problemów, pieściła się błyskotkami umysłu i wyobraźni, a teraz wobec bramy ciemnych zaświatów wątpić się zdaje, czy to wszystko, co żegna, nie było równie ułudną marą, jak cienie, do których zstępuje. Wierszyk ten w wielkiej swojej prostocie uwidocznia nam głęboką melancholię wieku, w którym nowa, lecz jeszcze nie dość poznana wieść i nauka krew świeżą i męską energię wlewała w życie, a śmierci blade przybytki rozjaśniała promieniami nadziei (ibid.).

W tłumaczeniu Zygmunta Kubiaka pożegnalny żal żałobny brzmi bardziej czule i nie wzbudza egzystencjalnej trwogi i uczuć przerażenia:

Duszyczko, kochana wędrowniczko,

Ciała gościu i wspólniczko

W jakie ty strony odejdziesz,

Bladziutka, naga, zziębnięta,

Gdzie żartować, jak zwykłaś, nie będziesz

(Kubiak 2003: 585).

Funeralny epigramat zrobił niemałą karierę w poezji europejskiej, a w tym polskiej (Czermińska 1992: 78-87). Jak to zbadała Anna Spólna, obecnym u Hadriana dualizmem duszy i ciała poeci powojenni zachwiali. Najbardziej radykalnie uczynił to Tadeusz Różewicz, który odwraca „najstarsze, tradycyjne sensy” toposu duszy:

[u niego] duszyczka nie jest już duszą, nie można jej pomóc modlitwą, choć, udręczona, prosi o nią. Jako „nic”, resztka pozostała po ciele, nędzna namiastka istnienia, stanowi twór urągający chrześcijańskim wyobrażeniom o prymacie duszy nad cielesną powłoką człowieka (Spólna 2007: 72-73).

Zaraz po wojnie religijność poezji Bąka została wyśmiana m.in. w ciętej, niesprawiedliwej i szyderczej, stylizowanej na litanię satyrze Różewicza Na Wojciecha Bąka (Różewicz 1946: 6).

W parafrazie Transkrypcja z cesarza Hadriana: Animula, vagula, blandula „duszyczka” mimo swej trwożliwości, pierzchliwości, przerażenia kosmiczną bezdennością tamtej strony, z ufnością czeka na porwanie przez „wicher” i „wędrówkę ponad światami”. Poeta podtrzymuje orficki, a w zasadzie już chrześcijański dualizm ciała i duszy w chwili śmierci, podczas której dusza opuszcza ciało, aby połączyć się z nim podczas zmartwychwstania w mocy Ducha Świętego do życia w wieczności. Dlatego u Bąka „duszka trwożliwa” jest wystawiona na „wiatr”, symbolizujący Ducha Świętego.

Poprzez starożytne dziedzictwo autor znajdował drogi ku „przestrzeni wiecznej”. Starał się, aby jego utwory, nie tracąc głęboko ukrywanych spoiw z arcydziełami, otwierały nowe i ożywcze duchowo perspektywy, gdyż to one są miarą sztuki i literatury. Transkrypcja z cesarza Hadriana, nawiązując do oryginału, przywiodła poetę do źródeł egzystencjalnej trwogi i eschatologicznej nadziei. Rozgrywa się dramat między pełną lęku koniecznością porzucenia zmysłowego świata i tęsknotą za nieznanym nowym, nigdy niekończącym się życiem. 
W wierszach $\mathrm{z}$ różnych lat poeta ponawia wizję, $\mathrm{w}$ której człowiek staje $\mathrm{w}$ bramie śmierci, a dusza odrywa się od ciała. W Zastygłych chwilach żegnanie ziemskiego istnienia nie napełnia się trwogą, jak w inskrypcji Hadriana, lecz - co zrozumiałe u tłumacza Księgi psalmów (Bąk 1979) - jest psalmicznie wyśpiewaną nadzieją na wyzwolenie z tragizmu doczesności:

Czuję już nieraz ową chwilę,

Gdy w grobie kształt się kruszy ręki -

I tylko pył jest w ziemi pyle,

Wolny od trwogi, próżny męki.

A dusza, zapomniawszy ciała,

Wzniesie się czysta i pogodna -

I czuję: oto uleciała,

Jak źródło chłodna, wiatr swobodna!

I czuję chwili owej piękno,

Gdy ciało wreszcie się spopieli -

I dreszcz mą smutną wstrząsa ręką -

I dusza moja się weseli!

(Bąk 1958: 90)

Wojciech Bąk, poeta wykształcony klasycznie, wielokierunkowo i wytrwale inspirował się kulturą i historią antyczną z wielu powodów. Odwołania do antyku pozwalały mu stawać u źródeł swoich przekonań, a w utworach uniknąć prezentyzmu. Motywy antyczne służyły Bąkowi do wzmacniania poczucia ponadczasowości i podtrzymywania wiary w „przestrzeń wieczną”. Zamykanie się w tym, co bieżące i tymczasowe, było według niego naganne. Dlatego twierdził: „Kto się zwiąże ze swoim wiekiem na śmierć i życie, niech się nie dziwi, że z nim zginie” (Bąk 1968: 285). Według poety duchowe związanie się z kulturą antyczną i jej ideami (jak np. orfizm) miały zapewnić dziełu trwałość.

Przedstawione spostrzeżenia dają podstawę do uznania Wojciecha Bąka za chrześcijańskiego neoklasycystę, który do „nowoczesności” w literaturze odnosił się krytycznie, a właściwie ją odrzucał.

\section{Bibliografia}

Alkar [Aleksander Kraushar] 1866. Tytan. Arion z Koryntu. Lipsk: wyd. Paweł Rhode.

Banach, Witold 2005. Ostrów pod znakiem pegaza. Literacki przyczynek do dziejów miasta. Poznań-

Ostrów Wielkopolski: Wydaw. Poznańskie, Muzeum Miasta Ostrowa Wielkopolskiego.

Bąk, Wojciech 1934. Brzemię niebieskie. Warszawa-Kraków: Wydawnictwo J. Mortkowicza, Towarzystwo Wydawnicze w Warszawie.

- 1936. Śpiewna samotność. Warszawa-Kraków: Wydawnictwo J. Mortkowicza, Towarzystwo Wydawnicze w Warszawie.

- 1937. „Tyberiusz. Dramat”. Prosto z Mostu 5-9, 11-14.

- 1948. Twarze. Opowiadania. Łódź-Wrocław: Wydawnictwo Władysława Bąka.

- 1958. Zastygłe chwile. Poznań: Wydawnictwo Poznańskie. 
- 1960. Szkice. Warszawa: Instytut Wydawniczy „PAX”.

- 1968. Wyznania i wyzwania. Wybór pism. Wyboru dokonal i przedmową poprzedził Stefan Jończyk. Warszawa: Instytut Wydawniczy „PAX”.

- 1971. O Bogu - Człowieku i apostołach. Warszawa: Instytut Wydawniczy „PAX”.

- 1979. Psalmy Dawidowe oraz Pieśni Brewiarza Rzymskiego. Tłum. i wstępem opatrzył Wojciech Bąk. Warszawa: Instytut Wydawniczy „Pax”.

- 1997. W samotności. Wybór, układ, posłowie Roman Bąk. Ostrów Wielkopolski-Poznań: Wydawnictwo „W drodze”.

- 2007. Miasto mego dzieciństwa. Red. Przemysław Klimek. Ostrów Wielkopolski: Muzeum Miasta Ostrowa Wielkopolskiego.

Borkowska, Ewa 2012-2013. „Kilka uwag o dorobku niepoetyckim Wojciecha Bąka. Proza”. Spotkania Humanistyczne. Międzynarodowy Interdyscyplinarny Periodyk Naukowy. International Interdisciplinary Scientific Journal 2-3: 87-96.

— 2016. „W kręgu pojęć poeta laureatus i poète maudit. Zapiski na marginesie życia i twórczości Wojciecha Bąka”. Inskrypcje 2: 71-82.

- 2017. „Niedokończona autobiografia Wojciecha Bąka. Odczytanie z perspektywy zglobalizowanego świata". W: Elżbieta M. Kur, Barbara Stelingowska (red.). Literatura i globalizacja. Siedlce: Wydawnictwo Uniwersytetu Przyrodniczo-Humanistycznego.

Chojnowski, Zbigniew 2011. „Tragiczny optymizm' - 'Rozważania prozatorskie’ Wojciecha Bąka”. W: Wojciech Bąk. Raje i apokalipsy. Studia i szkice o literaturze dwudziestowiecznej. Olsztyn: Wydawnictwo Uniwersytetu Warmińsko-Mazurskiego.

Czermińska, Małgorzata 1992. „Topos duszyczki we współczesnej poezji polskiej”. W: Alina Brodzka, Elżbieta Sarnowska-Temeriusz (red.). Topika antyczna w literaturze polskiej XX wieku. Wrocław: Zakład Narodowy im. Ossolińskich.

Czernik, Stanisław 1938. „Monologi anielskie”. Prosto z Mostu 14: 7.

Ćwiklak, Kornelia 2014. „Ostrów: miasto w twórczości pisarzy XX-wiecznych (Wojciech Bąk, Edzard Schaper, Jadwiga Żylińska i Kazimierz Radowicz)”. Rocznik Ostrowskiego Towarzystwa Naukowego 7: 9-26.

Herbert, Zbigniew 2008. Wiersze zebrane. Oprac. edytorskie Ryszard Krynicki. Kraków: Wydawnictwo a5.

Jaworski, Michał 2017. Nowoczesny Orfeusz. Interpretacja mitu w literaturze polskiej XX-XXI wieku. Warszawa: Instytut Badań Literackich PAN.

Kempiński, Andrzej Maria 2002. Stownik mitów muzycznych. T. 1: Ludy indoeuropejskie. Poznań: „Ars Nova".

Krawiecka, Ewa (red.) 2006. Z cienia niepamięci do światta: Wojciech Bąk, Kazimiera Itłakowiczówna, Roman Brandstaetter. Poznań: Wydawnictwo UAM.

Krokiewicz, Adam 1995. Zarys filozofii greckiej. Od Talesa do Platona. Arystoteles, Pirron i Plotyn. Warszawa: Aletheia.

Kubiak, Zygmunt 1993. Przestrzeń dzieł wiecznych. Eseje o tradycji kultury śródziemnomorskiej. Kraków: Wydawnictwo „Znak”.

- 2003. Literatura Greków i Rzymian. Warszawa: Świat Książki.

Kubski, Grzegorz 2006. „Zmienność form modlitewnych w powojennych wierszach Wojciecha Bąka”. W: Ewa Krawiecka (red.). Z cienia niepamięci do światta: Wojciech Bąk, Kazimiera Ittakowiczówna, Roman Brandstaetter. Poznań: Wydawnictwo UAM.

Meller, Arkadiusz 2009-2010. „Sztuka pod dyktatura Jerzego Waldorffa - szkic o relacjach między faszyzmem a kulturą na przykładzie Włoch Benito Mussoliniego". Historia i Polityka 2-3: $105-121$.

Morawiec, Arkadiusz 2016. „Tyberiusz według Jacka Bocheńskiego”. Zagadnienia Rodzajów Literackich 3: 31-39. 
Morawski, Kazimierz 1893. Dwaj cesarze rzymscy Tyberyusz i Hadryan. Kraków: Księgarnia Spółki Wydawniczej Polskiej.

Pytel, Jan Kanty 2006. „Biblijno-teologiczne walory Psałterza w przekładzie Wojciecha Bąka”. W: Ewa Krawiecka (red.). Z cienia niepamięci do światta: Wojciech Bąk, Kazimiera Ittakowiczówna, Roman Brandstaetter. Poznań: Wydawnictwo UAM.

Piotrowiak, Miłosz 2015. „Do-tkliwość wojny: Omijam czule trawy, kiedy idę droga... Wojciecha Bąka i Drach Szczepana Twardocha”. W: Mariusz Jochemczyk, Magdalena Kokoszka, Beata Mytych-Forajter (red.). Balaghan: mikroświaty i nanohistorie. Katowice: Wydawnictwo Uniwersytetu Śląskiego.

Pyzik, Tomasz 2007. Twórczość poetycka Wojciecha Bąka. Ostrów Wielkopolski: Muzeum Miasta Ostrowa Wielkopolskiego.

Ratajczak, Józef 1993. „Ten wariat, Wojciech Bąk”. Kultura 1/2: 154-170.

Ratajczakowa, Dobrochna 2006. „Tomasz Morus - dramat Wojciecha Bąka”. W: Ewa Krawiecka (red.). Z cienia niepamięci do światta: Wojciech Bąk, Kazimiera Itłakowiczówna, Roman Brandstaetter. Poznań: Wydawnictwo UAM.

Różewicz, Tadeusz 1946. „Na Wojciecha Bąka”. Szpilki 2: 6.

Siedlecka, Joanna 2005. Obtawa. Losy pisarzy represjonowanych. Warszawa: Wydawnictwo Prószyński i S-ka.

Sadowski, Witold 2009. „Kto i do kogo mówi w litanii poetyckiej? Wokół utworu Wojciecha Bąka Modlitwa do Marii Matki". Prace Filologiczne 57: 31-48.

Sikorski, Tomasz 2016. Bal maskowy. Wojciech Bąk (1907-1961). Biografia pisarza. Szczecin-Kraków: Wydawnictwa Naukowego Wydziału Humanistycznego Uniwersytetu Szczecińskiego „Minerwa”.

Spólna, Anna 2007. Nowe „Treny”. Polska poezja żałobna po II wojnie światowej a tradycja literacka. Kraków: Wydawnictwo Uniwersytetu Jagiellońskiego.

Sterna-Wachowiak, Sergiusz 1996. „Wojciech Bąk. Żyć w wieczności i słyszeć bicie zegara”. W: Romana Brzezińska (red.). Poznaniacy. Portretów kopa i trochę. Poznań: „W drodze”.

Troczyński, Konstanty 1938. „Próba bilansu pokolenia 'Skamandra”. Tęcza 2: 27.

- 2003. Zoil. Pisarz i strategia. Sztuka, etyka, naród. Brzozowsciana. Podał do druku i oprac. Krzysztof Krasuski. Kraków: Wydawnictwo Arcana.

Trzeciakowski, Wiesław 2007. „Nie śmierci się boimy, ale umierania'. Analiza wiersza IV z cyklu Wiersze szpitalne Wojciecha Bąka w kontekście sytuacji umierającego człowieka”. Edukacja Humanistyczna 1: 121-126.

Waldorff, Jerzy 1939. Sztuka pod dyktatura. Warszawa: Wydawnictwo: Biblioteka Polska.

Wiśniewski, Jerzy 1998. „Lira i struna w poezji Zbigniewa Herberta”. Acta Universitatis Lodziensis. Folia Litteraria Polonica 1: 109-126. 